\title{
Teaching Creative Abilities of Children in Music Education in the General School
}

\author{
Penka Pencheva Mincheva \\ Faculty of Musical Education, Department of Musical Education and Conducting, Academy of Music, Dance and Fine Arts, Plovdiv, \\ Bulgaria
}

\section{Email address: \\ pmincheva1935@abv.bg}

\section{To cite this article:}

Penka Pencheva Mincheva. Teaching Creative Abilities of Children in Music Education in the General School. International Journal of Literature and Arts. Special Issue: Musical Theory, Psychology, Pedagogy and Performing. Vol. 3, No. 5-1, 2015, pp. $31-36$.

doi: 10.11648/j.ijla.s.2015030501.14

\begin{abstract}
In a community, where the consumer's attitude in all aspects of life is ever more commonly observed, including in the area of culture, the problem of stimulating the creative impulse, of training the creative activity of adolescents, becomes especially important. Responsible for seeking the appropriate means and methods for the development of the creative abilities in children are the parents, tutors, teachers. An important role, in that relation, could be entrusted to the music teacher in the general school.
\end{abstract}

Keywords: Creative Abilities, Creative Activity, Music Teacher, Improvisation, Mass Music Education, General School

\section{Introduction}

The educative importance of composing music consists of forming a creative attitude of the person towards the surrounding reality. "The child's own creations, even if simplest, the child's own findings, even the most humble ones, the child's own thought, even the most naive - exactly that creates an atmosphere of joy, builds the person, teachers humaneness, stimulates the development of creative abilities" [2]. Creativity is an unconditional necessity in every profession. Without creativity, there is no development and progress. That is why, the goal of the creative musical tasks is not to prepare future professional composers, but for the creative activity, woken up through music, to be transfered later on into the whole life of the person, regardless of the profession they practice.

The other educative effect of children's musical creative tries is the increase, to a significant degree, of their interest towards the musical art. Asafyev wrote on this subject: "Everyone who has felt, even just a little, the joy of creativity in a certain area of art, would be capable of perceiving and valuing everything good, which is done in that area, and with a greater intensity than the one, who only passively perceives" [1].

\section{Subject, Goals and Tasks of the Study}

The subject of the present publication is the work of the music teacher with an experimental class from a general school. The pedagogic experiment, which will be described, was performed over the course of three consecutive school years, while the students in the first to the third year of school, participating in the work of the experimenter, were selected on a random principle. The lessons - two classes a week - were done according to the curriculum of the discipline Music.

The goal of the experimenter was to unveil the series of pedagogic methods, through which, during the class in Music, creative abilities are purposefully taught to children.

Together with the presentation of specific pedagogic methods, concrete solutions will also be suggested achievements of the young students.

The tasks, which I set forth, are:

a) Description of specific actions of teacher and students, which stimulate creative activity.

b) Finding the role and meaning of the creative tasks in the separate activities in the music lesson - performance and perceiving of music.

\section{Characteristics of Musical Creativity}

Reviewing the musical creativity process in a 
psychological aspect, we find two main cores - aesthetic position and creative imagination.

In the process of training and education, it is especially important to create in the adolescents an active aesthetic position. What is meant by aesthetic position is that ability of perception, which consists in evaluating actually existing objects in the surrounding environment, including their aesthetic value. The aesthetic perception is always emotionally colored. The images and impressions - acquired from the colors, forms, movements, sounds around us, perceived, analyzed and experienced as real facts, invoking a certain feeling, mood - represent the basis of the creative image in art. In other words, if one sees, when they are observing, and hears, when they are listening, they gather impressions, which could be conveyed through an artistic form. For directing students towards perceiving and experiencing the aesthetic in the world around us, teachers in the subjects from the aesthetic cycle could contribute a lot, because the creative abilities have to be taught from an early age. Favourable opportunities in that aspect are presented by the lesson in Music. Determining the main emotional content of a performed and perceived music is provisioned in all textbooks in music. The goal is perfectly clear - to create in children a conviction that each musical work conveys a specific emotional meaning, and, when communicating with the piece, we must feel what moved the author, what feeling he wants to invoke with it.

Together with the aesthetic position, an important role in the creative process has also the creative imagination. It has as basis specific impressions - images from reality. From this, it naturally follows that the greater life experience one has, the more impressions he has gathered and the richer imagination he/she would manifest in different situations. However, this is not exactly so - everyone, who has communicated with children, is left surprised by their incredible resourcefulness. An adult person gathers life experience, but, along with it, they gradually get used to certain reactions to specific events and life situations; to a certain extent, manifesting impressions, behavior, reactions become unified. Each age group has their own, unique merits and the transition from one group to another is not always related to acquisitions of traits.

It is known that before reacting to the semantic side of speech, the small child first reacts to the character of the intonation - affectionate, angry, calm. The child's sensitivity to the expressiveness of a melody, of speech, movements, colors, has to be used from an early stage in order to provide a creative situation during the lesson, to present and solve creative tasks.

Creative abilities are possessed by all children psychologists, studying child creativity, are certain of this. The reasons for this are many. The child is an explorer - they discover the world around themselves, and creativity includes sense of discovery. The perceptions of the child are bright, vivid, emotionally specific, because everything around them is new and interesting. The child possess spontaneity of expression, and the creative processes establishes the threeelement structure: the event, which has provoked interest experience - direct expression.

\section{Pedagogical Approaches for Stimulating Children's Musical Improvisations}

The tasks of composing a melody are realized individually. They are performed as early as the first grade and can be applied during several minutes in each class, according to the specifics of the corresponding lesson.

\subsection{Sequence of Work for Creating a Melody by the Students}

The teacher needs to know that the following order of actions is pedagogically correct and methodically justified:

1. The task has to be explained (the most basic creative task is the composition of a melodic conclusion - the teacher sings a melody, interrupting the performance just before the cadence, in order to direct the attention of the children towards what element of the melody they are expected to compose; and then, the teacher sings the conclusion), i.e. what has to be done is shown, using for that purpose an example, different from the one, on which the children will work;

2. The melody, on which the task of composing a melodic conclusion, is sung, time is left for everyone to find their own solution silently and then the teacher waits for volunteers who want to perform their suggestion;

3. The teacher points at the first student, who will perform their solution of the creative task;

4. The teacher sings the musical example specifically for that student and in the corresponding moment gives them a signal with their hand, to join in with their own suggestion;

5. Other students also offer their own solutions of the creative task (their own improvisation attempts);

6. The teacher carefully, very tactful and encouraging evaluates the individual suggestions.

\subsection{Preparatory Period}

The preparatory period, before moving on to actual musical improvisation, includes the following methods:

a) Rhythmic variants of short verbal forms, for example: "I am going for a walk" (figure N $1 \mathrm{a}, \mathrm{b}, \mathrm{c}$ ). 


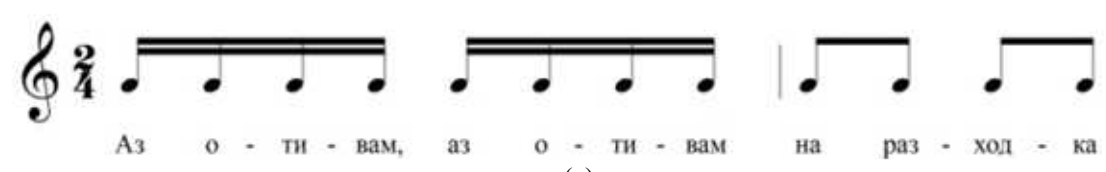

(a)

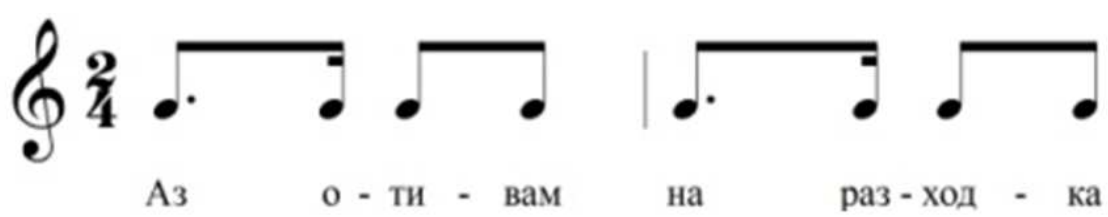

(b)

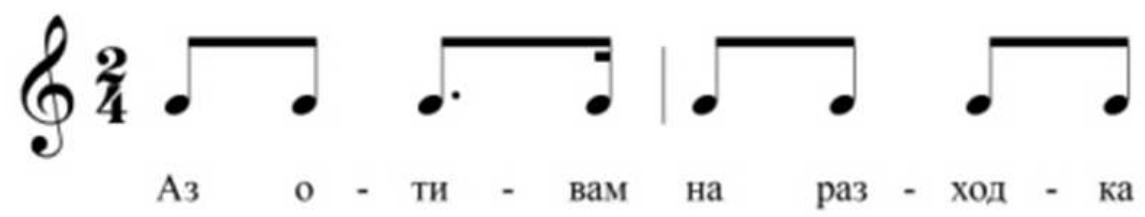

(c)

Figure No 1. Rhythmic variants of short verbal forms - "I am going for a walk".

All rhythmic variants, offered by the individual children, after the teacher has shown the initial model, can be performed consecutively or simultaneously; they can be transferred to percussion musical instruments. This can serve as accompaniment to a melody, which the teacher improvises on the given text.

b) Melodization of forenames, object names and other (Figure № 2).

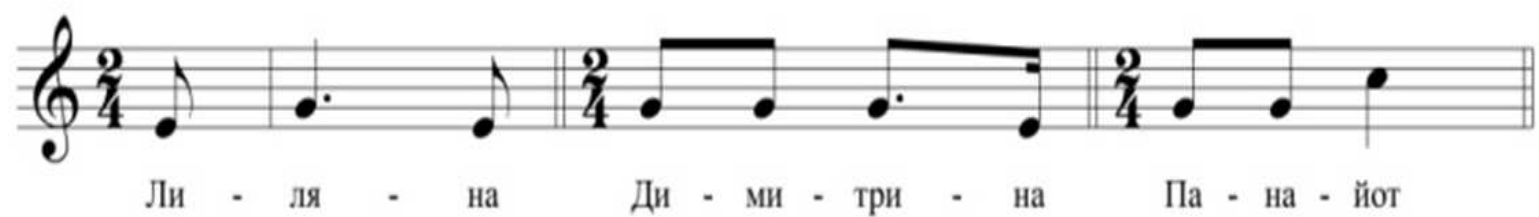

Figure No 2. Melodization of forenames.

\subsection{Forms of Work}

Specific forms of work on the children's musical improvisations are:

1. The most basic creative task for melodic improvisation is to complete a melody by by feel, i.e. composition of the melodic cadence. In this, as well as in the next tasks, the child, which is to improvise, is chosen in advance. In the moment, when the teacher interrupts the melody (before the last two-three tones) and gives a signal, the child joins in and sings the melodic conclusion, without breaking the melodic pulsation. If a different cadence is to be composed to the same melody by a different student, the teacher again performs the melodic structure and the student completes the melody after the given by the teacher signal. In creative tasks of the specified type, the singing of the melodic structure itself by the teacher already organizes and activates the musical thinking of the chosen student. One musical thought could have several different conclusions, so the attempts of the students have to be encouraged, while the most successful one among them has to be pointed out.

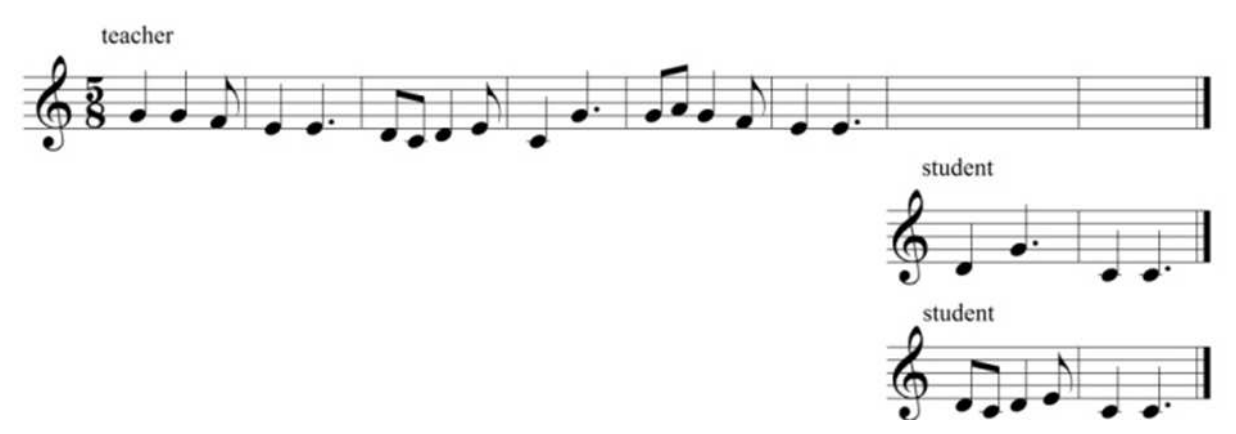

Figure No 3. Completing a melody. 
2. Composing a Seconda Volta. In this task, the condition is to remember the melody, to repeat it from the start and to change its ending so that it sounds complete.

3. Continuing a melody by by feel. Here, remembering the suggested by the teacher is not obligatory - the teacher sings the melodic construct, and on at given signal the preliminary chosen child freely continues and creates the cadence (Figure $\mathrm{N}$

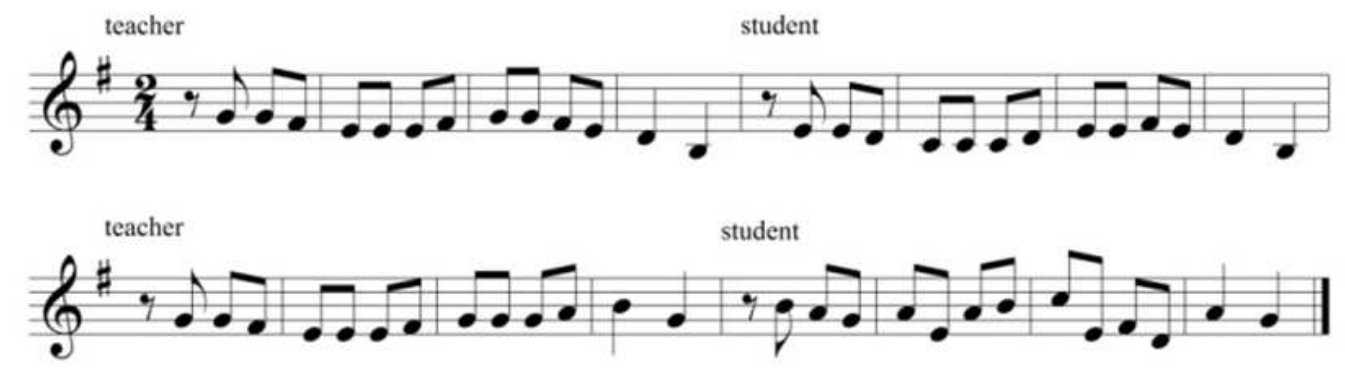

Figure No 4. Continuing a melody.

4. Composing a melody to a given methrorhythm. The rhythm is written with note values, so that it is visible to all students, after which it is voiced with a randomly chosen syllable, or with a percussion musical instrument. The performed methrorhythmic scheme calls associations with a melodic construct. Keeping with it is not obligatory - the task is to stimulate the child's fantasy.

5. Composing a melody on a specific methric pulsation (the methrum also has to be demonstrated). This task can be combined with the performance of the steps of a familiar to the students dance (for example, waltz, straight horo, rachenitza), which is used as a starting point of the melodic improvisation.

6. Composing a melody to a given harmonic scheme (Figure N 5).
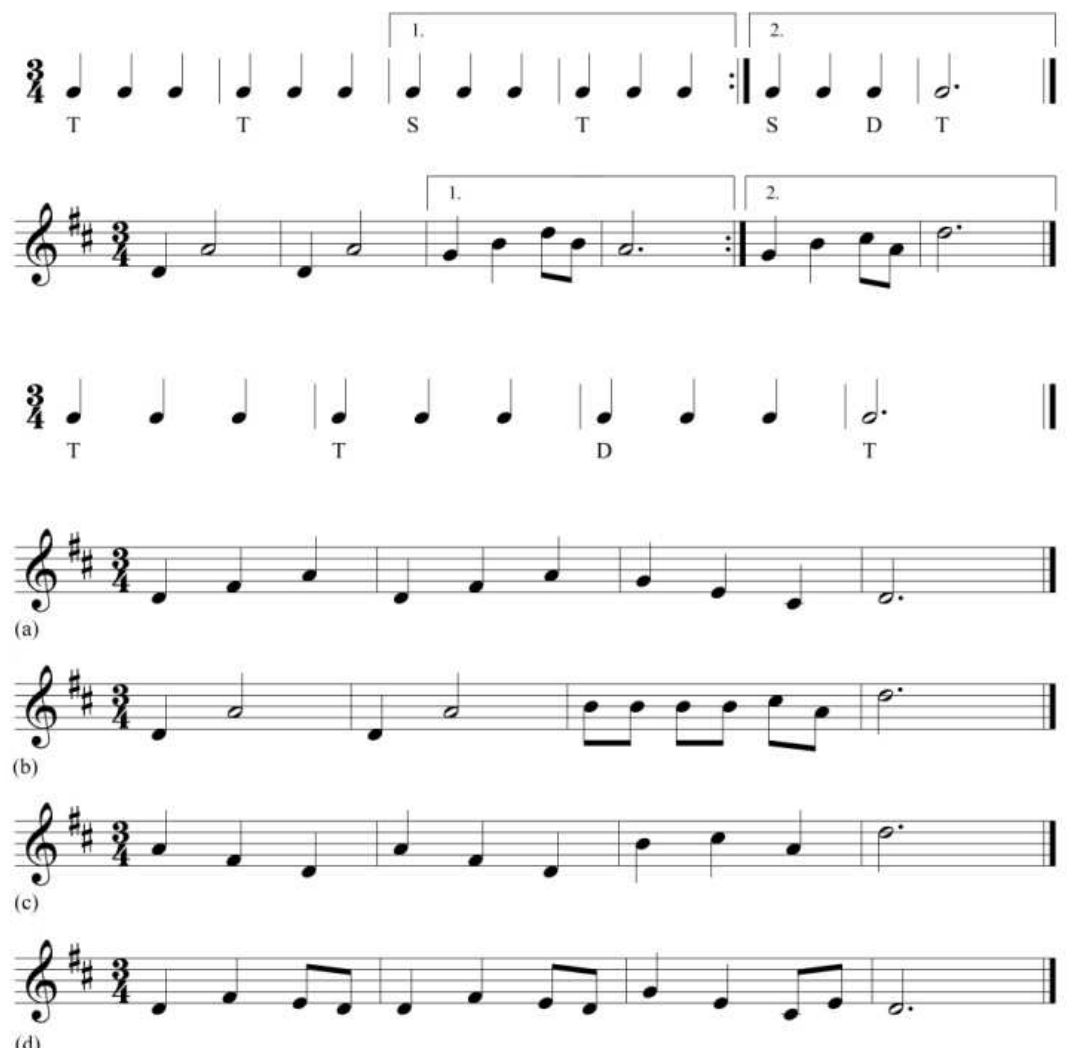

(d)

Figure No 5. Composing a melody to a given harmonic scheme.

7. Composition of variations on a provided musical theme. In this case, a bright melodic construct is sung, which has to be remembered precisely. The students improvise on that example and create similar, sometimes quite originally varied melodies. It is explained that at times only the rhythm could be changed, it is allowed to transform completely the measuring method, i.e. the methrum. There could be changes also to the melody itself, using additional tones and others 
(Figure N 6).

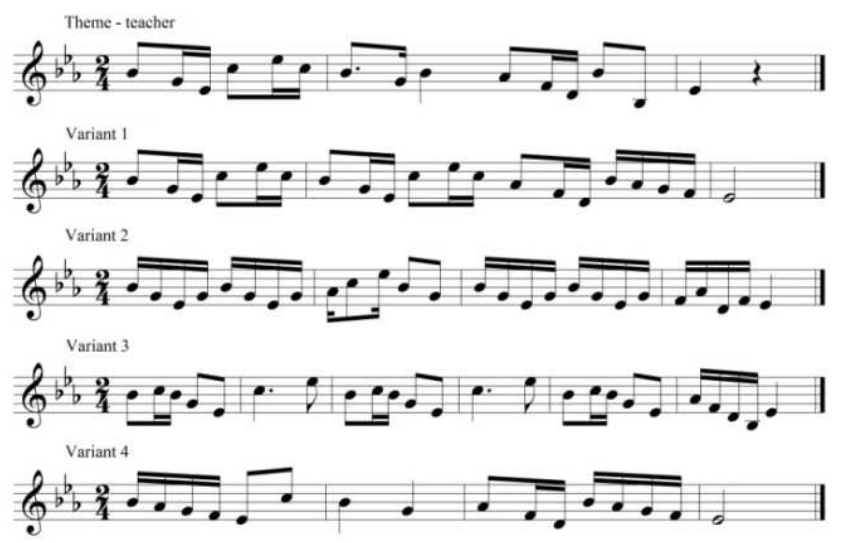

Figure No 6. Students' variations.

8. Composing a melody to given verses. Above all, it is necessary to read the text clearly and expressively. The children find what mood the poet has recreated, what has to be the character of the music, which will supplement and express with other (musical) means the impressions from the poetic text. A suitable approach is, after a discussion about the emotional content of the verses, the children to chant the text, in order to feel the methric pulsation. It is good to write down the poem in an appropriate way, so, in the course of work, it could be seen by all students, without the need for them to memorize it by heart. Afterwards, the class moves on to composing the melody. It is sung with the text right away, i.e. the verses are not spoken, but directly sung, intoned with the melody, which is being formed in that moment. In the initial attempts, the first verse could be sung by the teacher.
In this way, they introduce the children to a specific mode and tonality, set a methric pulsation and rhythmic organization of the tones (naturally in the next phrases, the rhythm cannot be completely different), the character of the music, the intonation style. If the children already have certain experience, the first verse is sung by a student right away. In this case, it is appropriate to hear several attempts by different children, since the reference point, i.e. the initial phrase of the melody is especially important, mostly from the viewpoint of correspondence between the character and the meaning of the verses and the type of intonation of the triggering point. When a suitable beginning is found, it is repeated, until it is memorized and the other children are encouraged to continue the melody. Thus, a musical sentence is formed by several suggestions. Practically, the whole class participates in the composing of the song. An accompaniment with percussion instruments is also prepared for the composed and approved by the class song. The song obtains a more complete look, if the teacher harmonizes it, composes a piano accompaniment, introduction, conclusion. Usually the children perform their own "works" with a lot of much enthusiasm. The tempo, dynamics, technic marks, breaths, type of sound are determined by the "authors". The text of the song "Don't be Sad, Green Fir Tree" (Figure № 7) contains two contrasting characters. After composing a sad melody to the lyrics of the first verse, the teacher sings only the first 4-5 syllables of the melody of the second verse. With this, they orient the students in the new intonation-imagery sphere, which the verse bears - in the cited example, the new character is expressed through a parallel major tonality.

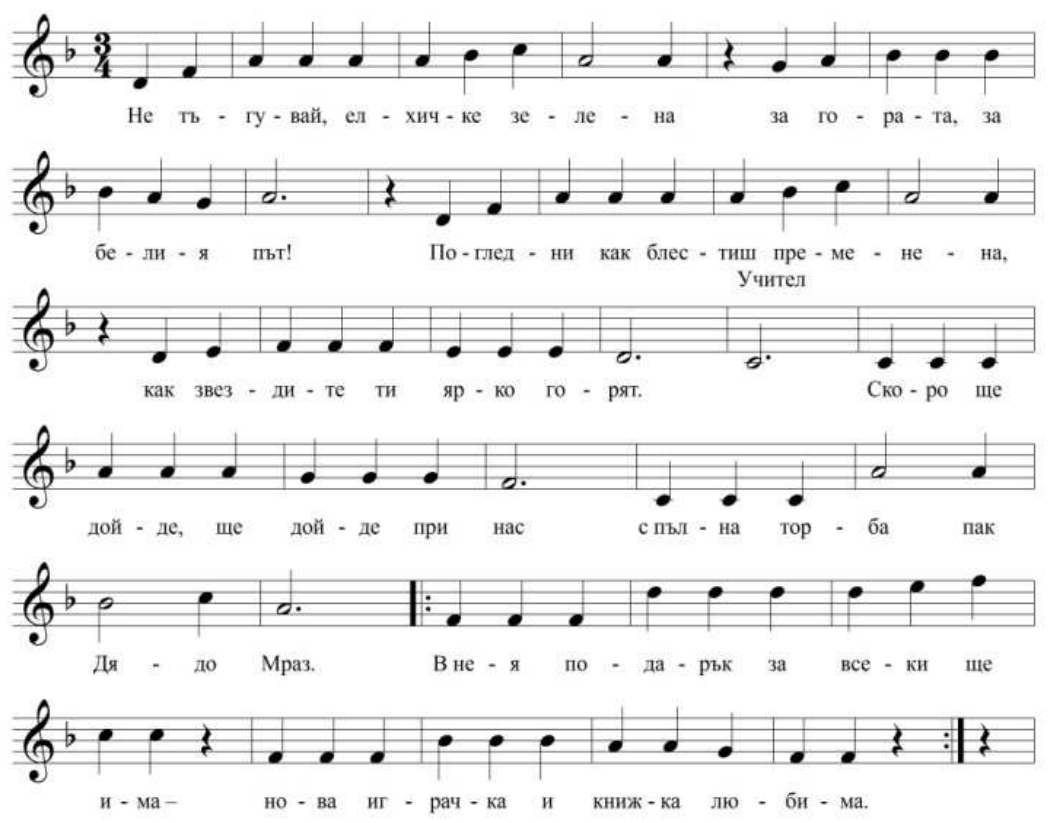

Figure No 7. "Don't be Sad, Green Fir Tree" composed by students of the third grade.

The composition of songs grew out to a preparation of a children's musical show - operetta. This particular activity allowed us to discover many "jobs", in which to engage each child from the class, with opportunities of expression, according to their musical-creative abilities. The students are explained that each "job" is important and needed for the 
success of the show.

The necessary "job positions" for the realization of the production are: composers (composing the melody), artists (presenting ideas for the stage design), playwrights (writing the dialogues and verses of the songs), judges (approving the different suggestions), authors of the accompaniment (composing an accompaniment for children's percussion musical instruments), performers (perform the stage production). The teacher is the director.

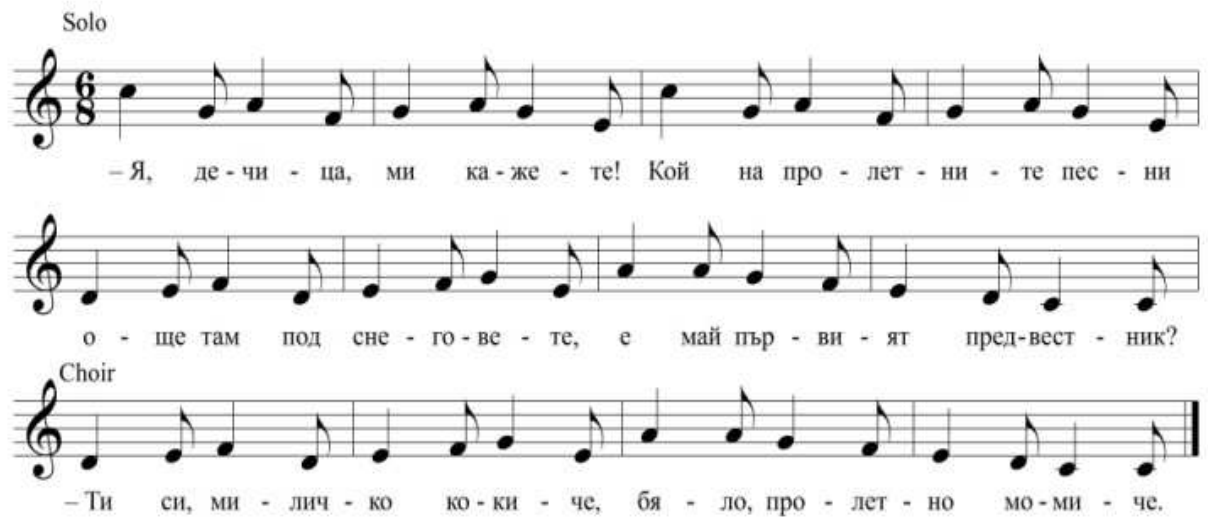

Figure No 8. "Well, children, tell me" - a song from children's operetta, composed by students of the second grade

1. Within the framework of the pedagogical experiment, many and varied songs were composed. These musical creations do not pretend for a high artistic value and their purpose, when being composed, was not such. They are simple, clear, logical and complete melodies with a specific emotional-image content, which allows for the pedagogical experiment to be deemed as successful. An argument in support to that statement are also the included examples - the songs, composed by the students.

2. When composing melodies, not all students of the class participated - the ones with lower levels of development of their musical pitch did not partake. In the creative process, however, which was unfolded in multiple aspects, opportunities were presented for the participation of each student.

3. The children learned to value and respect the artistic achievements of each student in the group, which had a great educational effect in the long term.

4. The young students got used to seeking that creative solution of a specific task, which is the most adequate and achievable by them, because they realized that the success, the end purpose - the operetta show or the concert was a collective work, in which the success of the team was important. Indeed, together with the active training of the creative abilities in the children, the second in importance result from the experiment was the acquirement of skills for working in groups - team work.

Regardless of the future professional realization of each of the children in the experimental class, especially important qualities, which gradually were being built and which are a serious basis for their future success, were the skills for creatively solving an arising task and the ability to work in a team.

\section{References}

[1] Asafyev, B. Of the Musical-Creative Habits of Children. In: Of Musical Training and Education, Sofia, 1979.

[2] Barenboim, L. Basic Education in the Carl Orff's System, Moscow, 1977.

[3] Gardner, Howard. Intelligence reframed. Sofia, 2004 (Гардньр, Хауърд. Нова теория за множествените интелигентности на 21. век. София, 2004)

[4] Heinrichs I. Musical Hearing and Its Development. Moscow, 1978 (Генрихс И. Музыкальный слух и его развитие. Москва, 1978)

[5] Mincheva, P. Musical Education in the General School. Sofia, 2009.

[6] Mincheva, P. Music and Intellect. Sofia, 1994 (Минчева, П. Музиката и интелектът. София, 1994)

[7] Mincheva, Penka. Musical Education in the General Education School. Sofia, 1994 (Минчева, Пенка. Музикалното възпитание в общообразователното училище. София, 1994)

[8] Nazaykinsky, E. Logic of Musical Composition. Moscow, 1982 (Назайкински, Е. Логика музыкальной композиции. Москва, 1982)

[9] Piaget, Jean. The Psychology of Intelligence. Moscow, 1992 (Пиаже, Жан. Психология интелекта. Москва, 1992)

[10] Skrebkov, S. Artistic Principles of the Musical Styles, Moscow.1973 г. (Скребков, С. Художественные принципи музикальных стилей, М.1973)

[11] Tarasova, K. Ontogenesis of Musical Abilities. Moscow, 1988 (Тарасова, К. Онтогенез музыкальных способностей. Москва, 1988) 